\title{
Селективни шийни дисекции и предложение за въвеждане на унифицирана терминология на български език
}

\author{
Д. Пазарджиклиев \\ УМБАЛ „Св. Георги“ ЕАД, УНГ-кЛиника - Пловдив
}

3 начението на унифицираната медицинска терминология е огромно. То се заключава във възможността специалистите да разменят помежду си достоверна информация. Освен всичко друго това позволява сравняемост на методите и резултатите, което е в основата на научните публикации.

Наличието на шийни метастази при карциномите на главата и шията е основен прогностичен фактор, определящ преживяемостта. Поведението по отношение на регионалния лимфен басейн, особено при клинично N0 се различава между отделните институции. По отношение $\mathrm{N}$ позитивния статус като че ли е налице по-голямо съгласие и в повечето случаи се препоръчва извършването на радикална шийна дисекция, особено при плоскоклетъчни карциноми, които са много агресивни. Въпреки това има и институции, които при N1 статус са склонни да прилагат селективни.

През последните десетина години у нас проблемът за регионалния лимфен басейн неизменно се разглежда на всеки научен форум. Появиха се и множество публикации и научни трудове. Въпреки това прави впечатление липсата на утвърдена терминология по отношение на видовете шийни дисекции. Естествено, терминологията у нас се пренася директно от англоезичната литература, като при това не се прави опит за тълкуване на значението ѝ. Нещо повече, в родните публикации съвсем свободно се въвеждат допълнителни термини, които задълбочават объркването.

Целта на настоящото съобщение не е да наложи алгоритъм за поведение при хирургичното лечение на регионалния лимфен басейн, а да внесе известна яснота по отношение на терминологията и да предложи класификация. 
Философията на различните видове шийни дисекции се основава, на първо място, на познанията за лимфния дренаж на карциномите на главата и шията. ${ }^{1,2,3}$ Класификацията им се изгражда на широко приетото и предложено от Memorial SloanKettering Cancer Center разделение на лимфните групи на шията и е предложена от Дружеството по хирургия на глава и шия към Американската академия по оториноларингология и хирургия на глава и шия (AAO-HNS). 4, 5, 6 Тя се изгражда на следните постулати: 1) радикалната шийна дисекция е стандартен метод на шийна лимфаденектомия, а всички други процедури представляват нейни модификации; 2) когато модифицирането на радикалната дисекция се изразява в запазването на една или повече нелимфни структури, се касае за модифицирана радикална дисекция; 3) когато модификацията запазва една или повече лимфни групи, които стандартно се премахват при радикалната, то тя се отбелязва като селективна шийна дисекция; 4) когато се премахват допълнителни лимфни групи или нелимфни структури, характерни за радикалната дисекция, се говори на разширена радикална шийна дисекция.

Проблемът в българската литература касае основно подхода при клинически N0 статус, при който в англоезичната литература се употребяват два термина: „elective“ и ,selective“ neck dissection. Директно преведени на български, и двата термина имат едно и също значение - по избор. Оттук произлиза и объркването при употребата им в българските публикации. Освен това в някои съобщения у нас, за да заместят предходните, се прибавят и термините консервативна и функционална шийна дисекция.

За да осветлим проблема, трябва да споменем, че при N0 статус има три подхода:

1. watch and wait или close follow-up - проследяване на шийния статус

2. лъчетерапия

3. elective neck dissection.

В последния случай се касае за извършването на дисекция на регионалния лимфен басейн при N0 статус по избор (elective) на хирурга (или според политиката на институцията), като не се влага смисъл относно анатомичния обем на дисекцията. Тъй като се касае за N0 статус, то тази „,elective neck dissection“ обикновено е ,selective“ по отношение на нивата, които се отстраняват. Това са нивата, в които обикновено метастазира туморът с конкретна локализация.

Както става ясно, elective и selective са два термина с различно значение, които не могат да се употребяват един вместо друг. Тъй като, когато се употребява „еlective“, се има предвид взимането на решение за извършване на шийна дисекция при N0 статус, ние предлагаме в такива случаи в българската литература да се приеме терминът ,профилактична шийна дисекция“. Поради факта, че е широко прието, че извършването на радикална дисекция при N0 статус е прекалено агресивно и излишно, то профилактичната шийна дисекция обикновено е селективна по отношение на отстранените нива на лимфни възли. Селективните дисекции са класифицирани като супрахиоидна, супраомохиоидна, латерална и т. н. Нивата, които се премахват при тези селективни дисекции, са подробно описани в литературата, но ще си позволим да ги припомним.

\section{Селективни шийни дисекции}

- Супрахиоидна - нива 1 и 2

- Супраомохиоидна - нива 1, 2 и 3

- Латерална - нива 2, 3 и 4

- Антеролатерална - нива 2, 3, 4 и 6

- Постеролатерална - нива 2, 3, 4 и 5

- Модифицираната радикална дисекция бива 3 вида според това кои от трите значими нелимфни структури се запазват:

- Модифицирана радикална тип 1 - нива 1 до 5 със запазване на n. accessorius

- Модифицирана радикална тип 2 - нива 1 до 5 със запазване на $n$. accessorius и v. jugularis interna

- Модифицирана радикална тип 3 (тип Восса) или още функционална - нива 1 до 5 със запазване на $\mathrm{n}$. accessorius, v. jugularis interna m. и sternocleidomastoideus.

Трябва да отбележим, че у нас се употребяват и термини като функционална и консервативна шийна дисекция в смисъл, в който в тях се включват различни селективни дисекции. Това е неправилно, тъй като в англоезичната литература те обозначават техниката, описана от Suarez и Bocca, за премахване на нива 1-5 със запазване на мускул, вена и нерв и наречена днес модифицирана радикална дисекция тип 3 или функционална шийна дисекция. ${ }^{7,8,9}$ Считаме, че за да се избегне объркването, тези термини не бива да се употребяват. Друг израз, който често се употребява у нас, е моноблок или en block, като смисълът, който се влага в това, не е много ясен. Те касаят хирургичната техника на шийната дисекция, която може да се различава между отделните институции и хирурзи. Трябва да подчертаем, че когато се 
използват тези термини, те не означават отделянето на лимфните възли от определени нива в един отделен препарат, а отделянето на лимфните възли ведно с първичния тумор, което може да е технически трудно.

Ние предпочитаме термина en block дисекция и винаги се стремим да отделяме лимфните структури и първичния тумор в един препарат, независимо от обема на лимфната дисекция.

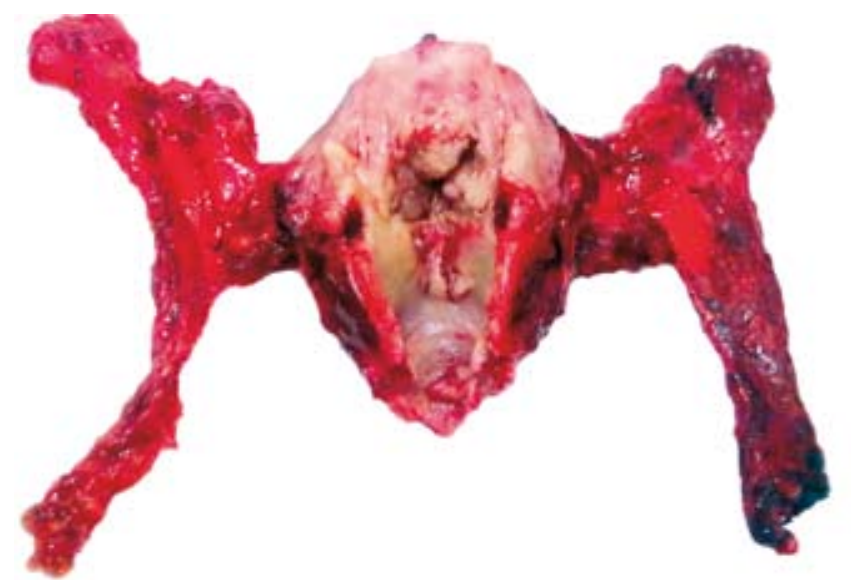

Фиг. 1. Тотална ларингектомия ен блок с двустранна селективна латерална шийна дисекция при срединно разположен тумор на ларинкса

2) при позитивен $\mathrm{N}$ статус обикновено извършвамe en block дисекция - радикална от страната на $\mathrm{N}+$ тумора и евентуално профилактична селективна от страната на N0 (фиг. 3) При двустранен N+ статус обикновено извършваме радикална от стра-
В заключение бихме желали да заявим, че в нашата практика ние сме приели следния подход:

1) при N0 статус в зависимост от локализацията и обема на първичния тумор ние извършваме по възможност en block едностранна или двустранна профилактична шийна лимфна дисекция, която обозначаваме според премахнатите лимфни нива от супрахиоидна до модифицирана радикална шийна дисекция 1,2 или 3 (фиг. 1, 2).

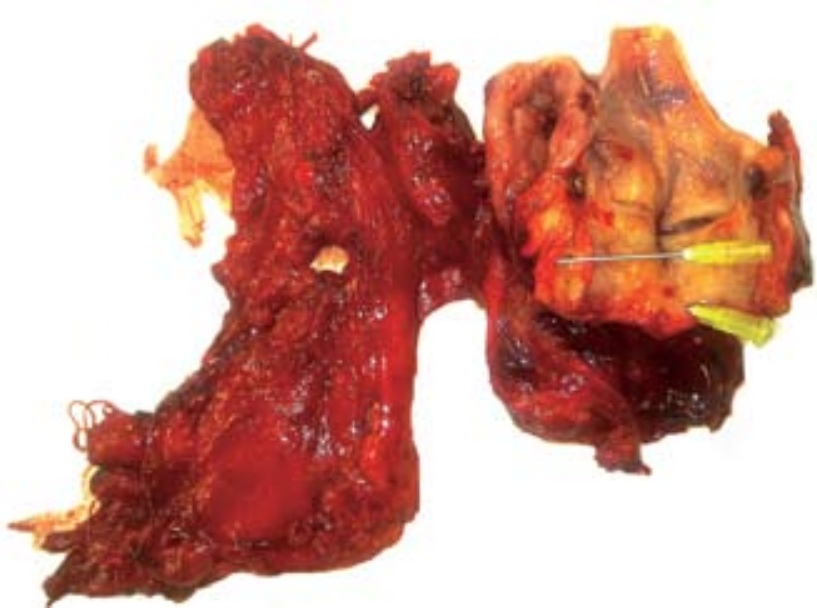

Фиг. 2. Тотална ларингектомия ен блок с постеролатерална шийна дисекция (нива 2-5) с включен лоб на щитовидна жлеза при ТЗ карцином на синус пирифрормис

на на по-високия $\mathrm{N}$ и модифицирана радикална от страна на по-ниския със запазване на вена югуларис и в изключително редки случаи двустранна радикална на един етап.
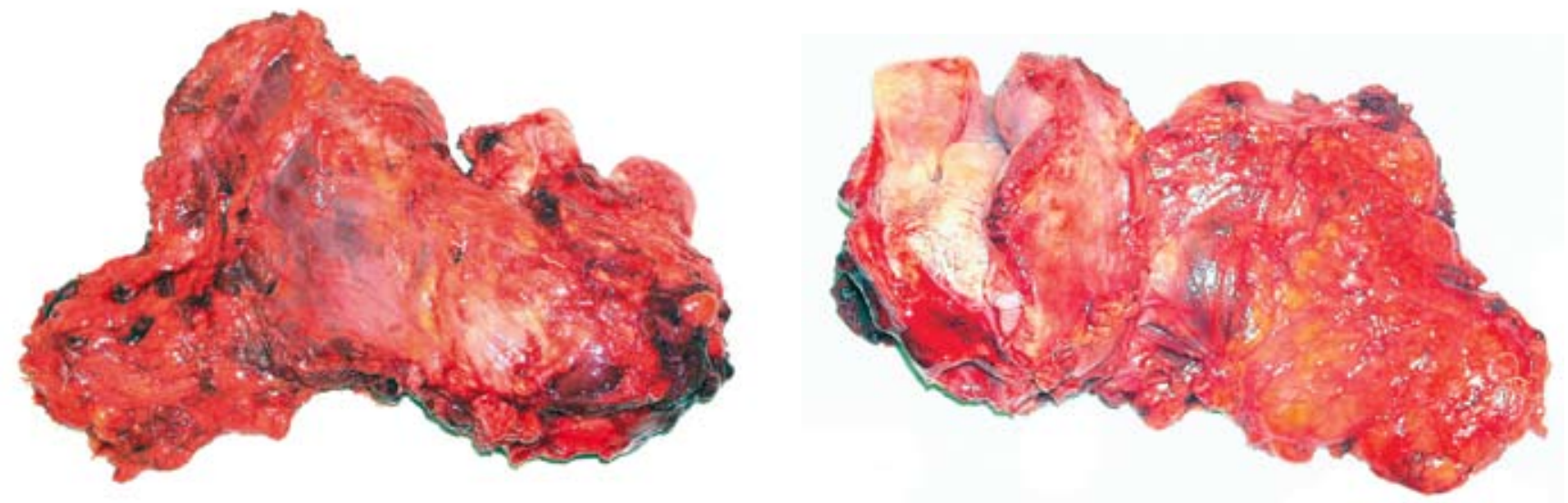

Фиг. 3, 4. Тотална ларингектомия с парциална фрарингектомия en block с радикална дисекция при карцином на синус пириформис 
Надяваме се настоящата публикация да предизвика дискусия и на следващ национален форум да бъде утвърдена българска терминология и поведение по отношение на регионалния лимфен басейн.

\section{Литература}

1. Fisch UP, Sigel ME. Cervical lymphatic system as visualized by lymphography. Ann Otol Rhinol Laryngol. Dec 1964; 73: 870-82

2. Lindberg R. Distribution of cervical lymph node metastases from squamous cell carcinoma of the upper respiratory and digestive tracts. Cancer. Jun 1972; 29(6): 1446-9

3. Shah JP: Patterns of lymph node metastases from squamous carcinomas of the upper aerodigestive tract, Am J Surg 160(4): 405, 409, 1990

4. Shah JP and others: Neck dissection: current status and future possibilities, Clin Bull 11: 25, 1981

5. Robbins KT, Medina JE, Wolfe GT, Levine PA, Sessions RB, Pruet CW (1991) Standardizing neck dissection terminology. Official report of the Academy's Committee for Head and Neck Surgery and Oncology. Arch Otolaryngol Head Neck Surg 117: 601-605

6. Robbins KT, Denys D, Committee for Neck dissection classification, American Head and Neck Society (2000) The American Head and Neck Society's revised classification for neck dissection. In: Johnson JT, Shaha AR (eds) Proceedings of the 5th International Conference in Head and Neck Cancer. Omnipress, Madison, Wis., pp 365-370

7. Suarez O: El problema de las metastasis linfticas y alejadas del cancer de laringe e hipofaringe, Rev Otorhinolaringol 23: 83, 1963

8. Bocca E, Pignataro O: A conservation technique in radical neck dissection, Ann Otol Rhinol Laryngol 76: 975, 1967.

9. Grenman R Principles and Techniques of Neck Dissection In: Anniko M, Bernal-Sprekelsen M, Bonkowsky V, Bradley S, Iurato S (eds) Otorhinolaryngology, Head and Neck Surgery Springer-Verlag Berlin Heidelberg 2010 pp 702 